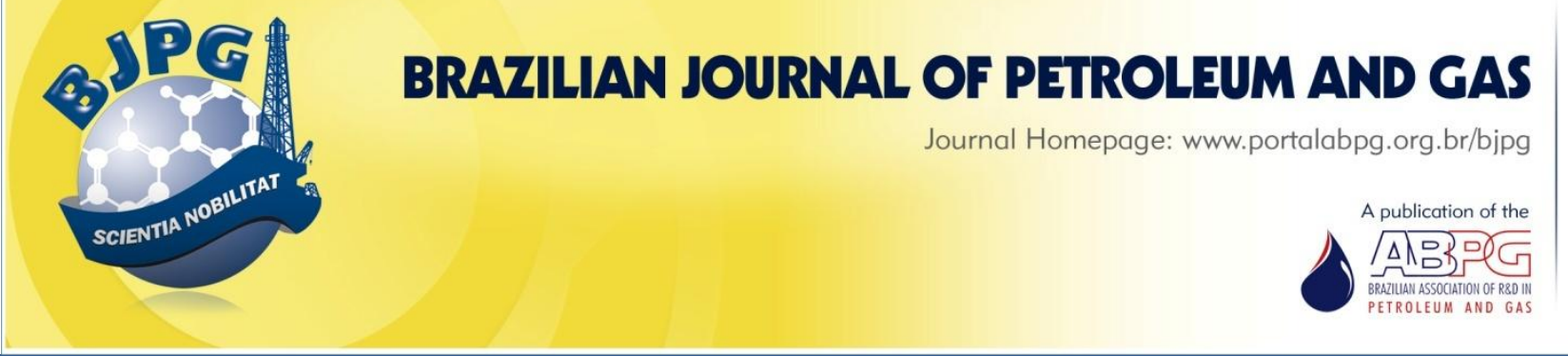

\title{
IMPLEMENTING ARTIFICIAL NEURAL NETWORKS MODELLING AFTER THE TREATMENT OF OIL REFINERY EFFLUENTS USING ADVANCED OXIDATION PROCESSES
}

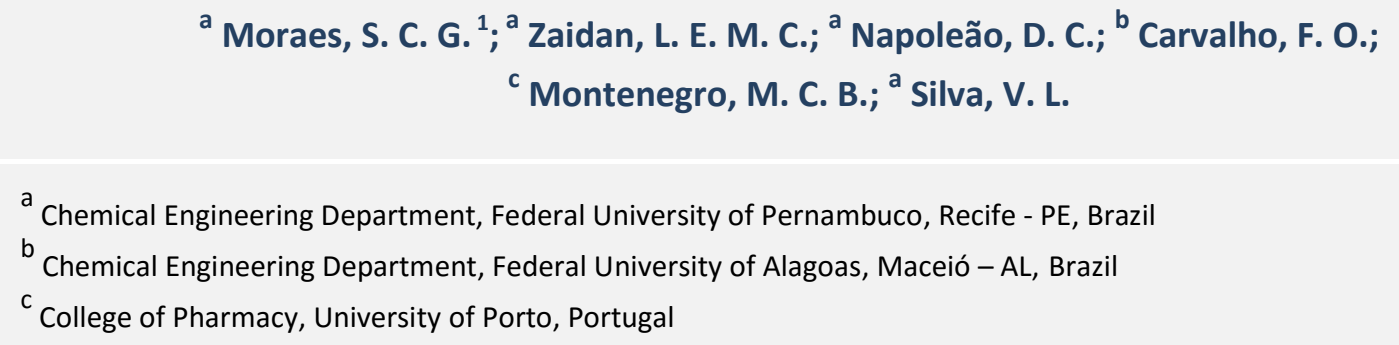

Received: 05.01.2016 / Revised: 17.03.2016 / Accepted: 21.03.2016 / Published on line: 06.04.2016

\begin{abstract}
The present study aims at evaluating the treatment of polycyclic aromatic hydrocarbons (PAH) present in oil refinery effluents by advanced oxidation process (AOP), besides analysing the data obtained using artificial neural networks (ANN). The AOP process managed to degrade 10 different PAH initially found in the samples analysed. The efficiency analysis of the process was also evaluated, according to the amounts of total organic carbon (TOC). The ANN Multilayer Perceptron used consisted of 3 layers. Experimental and simulated data used in the training were compared in both trial and validation processes concluding that the amounts were very similar. The network used was able to monitor precisely the tendency of the data and the amounts of TOC, observing the correlation coefficient on both modelling strategies employed. The values of $R^{2}$ were 0.994 in the first modelling, using the activation function logsig, and 0.996 in the second one, using tansig. Both modelings used the training algorithm Levenberg- Marquardt, corroborating the efficiency of the process employed.
\end{abstract}

\section{KEYWORDS}

wastewater treatment; polycyclic aromatic hydrocarbons; photo-Fenton; artificial neural networks

\footnotetext{
${ }^{1}$ To whom all correspondence should be addressed.

Address: Universidade Federal de Pernambuco, Departamento de Engenharia Química, Av. Professor Moraes Rego, 1235, Recife - PE - Brazil.

ZIP Code: 50670-901 | Telephone: +55 81 2126-7290 |e-mail: msibria@yahoo.com doi:10.5419/bjpg2016-0003
} 


\section{INTRODUCTION}

Crude Petroleum is a volatile mixture of organic and inorganic compounds, mainly consisting of aliphatic and aromatic hydrocarbons. This complex mixture also contains, in smaller amounts, nitrogen, oxygen, sulphur, and metallic ions- mainly nickel and vanadium (Falla et al., 2006).

Through the refining process, petroleum can generate more useful products, such as gasoline, kerosene, lubricants, nafta, and diesel. During the refining process, 246 to 340 liters of water per crude oil barrel are used, in average; generating amounts of residue water of between 0.4 to 1.6 times the volume processed (Alva-Algaéz, 2007; Misiti et al., 2013; Mizzouri et al., 2013). These activities generate effluents that present a broad variety of high toxicity pollutants, severely harming living organisms, among other factors, due to their carcinogenic properties, even when present in concentrations below lethal (Khan et al. 2015; Santaella et al., 2009; Kulkarni et al., 2013).

Among the pollutants present in petroleum and its products, the polycyclic aromatic hydrocarbons (PAH) should be pointed out. PAH are biorefractory, hydrophobic, and recalcitrant (Enell et al., 2004; Khowatimya et al., 2014; Xia et al., 2015). According to Wang et al. (2009), these compounds have caused alterations in the reproductive organs of fish that live in water contaminated with industrial residues derived from petroleum. In Brazil, however, there is no specific legislation in place to regulate the release of $\mathrm{PAH}$ into the environment; therefore, it follows the Dutch Environmental Guidelines and Standards for Soil and Groundwater (Jacques et al., 2007).

Although there are hundreds of PAH present in the environment, the United States Environmental Protection Agency (USEPA) and the National Institute for Occupational Safety and Health (NIOSH) indicate that, for regulatory purposes, the presence of 16 compounds considered of priority should be monitored. Among these compound are naphthalene, acenaphthene, fluorene, phenanthrene, anthracene, fluoranthene, pyrene, benzo[a]anthracene, chrysene, benzo[e]pyrene, benzo[b]fluoranthene, benzo[k]fluoranthene, benzo[a]pyrene, di-benzo[a,b]anthracene, benzo[g,h,i]perylene, and indeno[1,2,3-cd]pyrene. Due to the high toxicity of these pollutants, the
USEPA has developed methods to monitor their presence in the environment; being gas chromatography in combination with mass spectrometry (GC/MS) and the analysis of total organic carbon (TOC) commonly carried out for this purpose (Cotta et al., 2008; Visco et al., 2005). The use of chromatography allows to identify the different compounds in the different concentration levels safely (Costa, 2007).

While developing an analytical technique capable of verifying the presence of $\mathrm{PAH}$, it is important to analyse the effectiveness of the different types of water treatment. In oil refineries, it is common to rely on physicochemical treatments such as water-oil separator and coagulation-flocculation. These treatments can be followed by biological treatments, because of the recalcitrant property of the compounds after conventional treatments, which require the use of polishing processes, such as the advanced oxidation processes (AOP) (Stepnowski et al., 2002; Hu et al., 2015; Xu et al., 2015; Kim et al., 2006).

Among the AOP, the photo-Fenton process should be highlighted as an efficient process in the formation of hydroxyl radicals, since it presents low operational cost when compared to other AOP (Khataee \& Kasiri, 2010). According to Ana et al. (2005), a variant of the photo-Fenton process (photo-Fenton-like process) has been successfully employed, as the treated samples already presented amounts of iron to be used as catalysts in the reaction, reducing operational costs.

Due to the complexity of the reactions involved in the AOP, it has been difficult to determine kinetic parameters, leading to uncertainties in projects and scale-up of chemical reactors of industrial interest. Consequently, the photocatalytic modelling using artificial neural networks (ANN) has been used substantially Kim et al. (2006). The use of ANN in degradation reactions employing AOP has proven to be very efficient, due to the difficulty in determining the different operational parameters involved (Khataee \& Kasiri, 2010).

The ANN have been of great interest, for they are predictive models and of pattern recognition with the capacity to "learn" from observed experimental data without knowledge of the laws of physics and chemistry that control the system. 
Therefore, the use of ANN in data handling is specially important in non-linear and complex behaviour systems (Khataee \& Kasiri, 2010; Ebrahimzadeh \& Khazaee, 2010; Jalil et al., 2014).

Employing mathematical modelling, the ANN allows the simulation of different processes involved in the treatment of effluents. The use of the ANN makes it possible to evaluate the complexity of the reaction mechanism of the photochemical processes, given the difficulties in the determination of the phenomenological models due to the non-selectivity of hydroxyl radicals (Khataee \& Kasiri, 2010).

The current work aims to evaluate the efficiency of the treatment of effluents of an oil refinery unit using advanced oxidations processes and modelling via artificial neural networks.

\section{MATERIALS AND METHODS}

\subsection{Collecting the effluent from the oil refinery}

Three samples were collected from five different points of treatment plants from an oil refinery located in the city of Rio de Janeiro. The points were: AMG (entry of the treatment plant), AJQ (sample from the aerobic incubator), APM (water from the separator outlet), API (in the Dissolved air Floating Filter and before the bioreactor), APL (sludge from the bioreactor), and APN (water from the final effluent outlet, to be disposed in the river). The samples were collected in three consecutive days, until reaching a total volume of $5 \mathrm{~L}$ for each point, according to the requirements set by NBR $9898 \mathrm{Nb}$ 1050, the norm which regulates Preservation and Effluents Sampling Techniques.

\subsection{Total organic carbon analysis}

The total organic carbon (TOC) was determined in a high-sensitivity equipment (SHIMADZU), TOC/VCPN model. The quantification of organic matter was carried out using a high-sensitivity catalyst $\left(4 \mu \mathrm{g} \cdot \mathrm{L}^{-1}-25,000 \mathrm{mg} \cdot \mathrm{L}^{-1}\right)$, with the capacity to identify the amounts of total carbon (TC) and inorganic carbon (IC). The pressure was maintained between 300 and $500 \mathrm{kPa}$ with a flow of $150 \mathrm{~mL}$ $\min ^{-1}$.

\subsection{PAH analysis by gas chromatography with detection by mass spectrometry (GC/MS)}

The samples were analysed in a gas chromatograph connected to a mass spectrometer (SHIMADZU), QP201 Plus model. To determine the 16 PAHs considered as priority, a methodology proposed by the USEPA 8270-D was used (APHA, 2013). The parameters considered were: temperature of the injector $\left(250^{\circ} \mathrm{C}\right)$, interface temperature $\left(300^{\circ} \mathrm{C}\right)$, flow of helium gas $(1.20$ $\left.\mathrm{mL} \cdot \mathrm{min}^{-1}\right)$, injection volume $(1 \mu \mathrm{L})$, injection mode (splitless), and temperature gradient (ranging from $45 \pm 1^{\circ} \mathrm{C}$ to $310 \pm 1^{\circ} \mathrm{C}$ ).

In the sample preparation stage, the liquidliquid extraction process (LLE) was used, having dichloromethane as a solvent. The liquid-solid extraction process (LSE), with a Soxhlet device at $60 \pm 1^{\circ} \mathrm{C}$, used hexane-acetone (Merck) in a 1:1 proportion, followed by a filtration cleanup. The filtration used a clean up column filled with sodium sulphateanhydrous calcined, silica gel and basic silica, as shown by the diagram in Figure 1. This column was initially washed with $50 \mathrm{~mL}$ of a dichloromethane mixture and hexane 2:23, followed by the same mixture in the proportion of $3: 27$. The resulting liquid from the filtration was submitted to a LLE, using dichloromethane as a solvent following, in both cases, the methodology used for the PAH, regulated by USEPA 3540 .

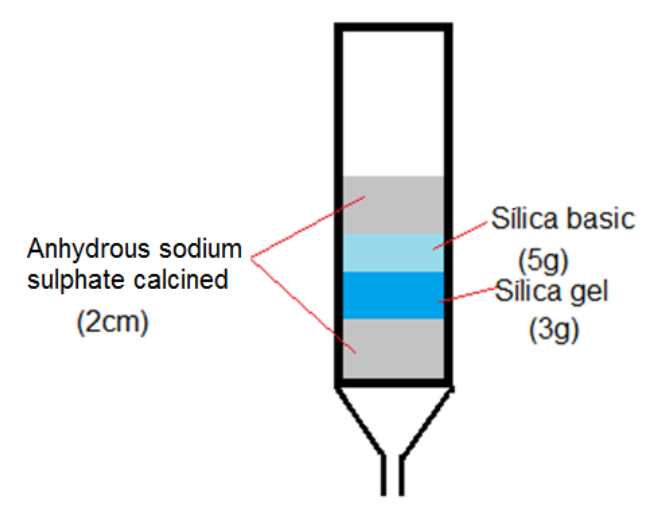

Figure 1. Diagram for the cleanup stage. 


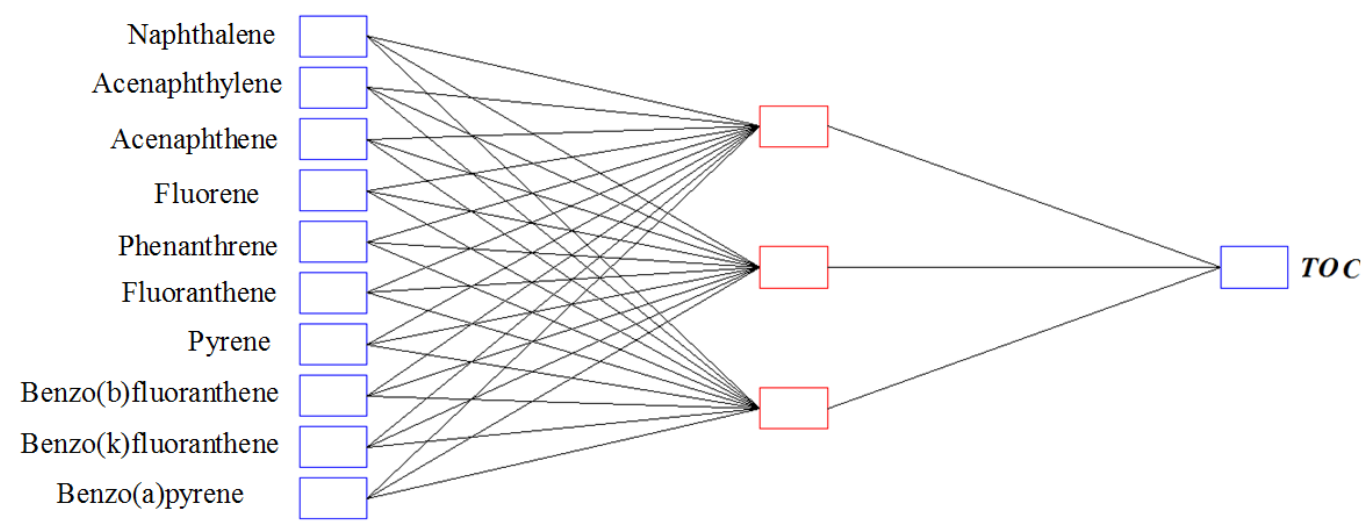

Figure 2. First ANN modelling strategy.

The extracts obtained for both extraction types carried out were concentrated until a volume of $2 \mathrm{~mL}$, using a rotary evaporator (Fisatom), model 801 , for further analysis in the GC/MS.

\subsection{PAH degradation via photo-Fenton like process in a bench reactor}

The trials involving the advanced oxidation processes (AOP) were run in a homogenous system, photo-Fenton like, in bench reactors, using UV-A radiation. The reactor used consisted of three lamps in parallel, with a power of $20 \mathrm{~W}$ each. In the determination of PAH and TOC amounts, an inhibitory $0.1 \mathrm{M}$ solution from the mixture sodium hydroxide, potassium iodate, and sodium nitride was used to guarantee the stagnation of the AOP reaction for analysis. The iron used in this treatment was endogenous, it was part of the sample itself. The first variable analyzed was the concentration of hydrogen peroxide $(30 \% \mathrm{w} / \mathrm{w}$, Merck, Brazil), which was calculated based on COD values. In view of the need for a large data to obtain the neural network, experiments were conducted with three different concentrations of hydrogen peroxide: 60,95 , and $130 \mathrm{mmol}$. The second variable was analyzed during the degradation time, which was also assessed in three different values $(30,75$, and $120 \mathrm{~min})$. The sample volume was $50 \mathrm{~mL}$.

\subsection{AOP analysis and the use of artificial neural networks (ANN)}

Two strategies were used to employ the ANN in the AOP modelling studied. The first consisted in correlating the inputs (naftalene, acenftilene, acenaftelinr, fluorene, fenantrene, fluorantene, pyrene, benzo(b)fluorantene, benzo(a)pyrene and peroxide) with an output (total organic carbon), according to the diagram in Figure 2. ANN was used for modelling the logsig activation function applying the Levenberg- Marquardt training algorithm.

The second strategy used the same input and output, adding the time variable only to the input and removing the TOC variable. This second modelling strategy aimed at a possible optimisation of the process, taking into consideration the optimal time for the degradation of composites and the mineralization of organic matter. For this strategy the tansig activation function were used in the intermediary and exit layers. The Multilayer Perceptron (MLP) network consisted of: 1) entry layer with 11 neurones, 2) intermediary layer containing 3 neurones, and 3) exit layer with 1 neurone. The MPL was used to model the tansig activation function applying the LevenbergMarquardt training algorithm.

The choice of the variables, $\mathrm{H}_{2} \mathrm{O}_{2}$ and time, was determined based on the the studies, as well as the levels of $\mathrm{H}_{2} \mathrm{O}_{2}\left(60,95\right.$ and $\left.130 \mathrm{mmol} . \mathrm{L}^{-1}\right)$ and amounts of time (30, 75 and $120 \mathrm{~min}$ ) (Napoleão et al., 2013; Durigan et al., 2012; Liu et al., 2012). This way, the efficiency of the process was evaluated in function of the PAH degradation of the TOC analysis and the modelling using ANN. 
Table 1. PAH concentrations of the five samples analysed via GC-MS.

\begin{tabular}{cccccc}
\hline & \multicolumn{5}{c}{ Concentration $\left(\boldsymbol{\mu g} .^{-1}\right)$} \\
\cline { 2 - 6 } PAH & AGM & AJQ & APM & APN & APL \\
\hline Naphthalene & 371.47 & 835.27 & 1.09 & 2.04 & 161.20 \\
Acenaphthylene & 1.83 & 2.57 & 6.23 & 1.51 & 116.96 \\
Acenaphthene & 8.15 & 7.97 & 11.63 & 22.04 & 1.92 \\
Fluorene & 29.49 & 6.12 & 39.11 & 67.32 & 6.38 \\
Phenanthrene & 24.86 & 13.64 & 38.36 & 57.70 & 13.34 \\
Fluoranthene & 1.11 & 1.52 & 4.16 & 2.21 & 13.96 \\
Pyrene & 4.32 & 5.70 & 39.61 & 18.55 & 3.79 \\
Benzo(b)fluoranthene & 0.16 & 0.10 & 9.41 & 0.28 & 4.81 \\
Benzo(k)fluoranthene & 0.11 & 0.19 & 3.02 & 0.73 & 2.38 \\
Benzo(a)pyrene & 1.76 & 6.52 & 24.54 & 0.54 & 66.10 \\
\hline
\end{tabular}

Table 2. PAH concentration, TOC content and percentage of degradation of the five samples after being submitted to the photo-Fenton process.

\begin{tabular}{|c|c|c|c|c|c|c|c|c|c|c|}
\hline \multirow[t]{2}{*}{ PAH } & \multicolumn{4}{|c|}{$\begin{array}{l}\text { Concentration } \\
\left(\mu \mathrm{g} \cdot \mathrm{L}^{-1}\right)\end{array}$} & \multicolumn{5}{|c|}{$\begin{array}{c}\text { Percentage of Degradation } \\
(\%)\end{array}$} & \multirow[b]{2}{*}{ APL } \\
\hline & AGM & AJQ & APM & APN & APL & AGM & AJQ & APM & APN & \\
\hline Naphtalene & 5.06 & 1.21 & 0.57 & 0.32 & 0.47 & 98.6 & 99.9 & 47.1 & 84.3 & 99.7 \\
\hline Acenaphthylene & ND & 0.19 & 0.18 & 0.17 & 0.18 & 100.0 & 92.6 & 97.1 & 88.7 & 99.8 \\
\hline Acenaphthene & 0.19 & 1.06 & 0.17 & 1.00 & ND & 97.7 & 86.7 & 98.5 & 95.5 & 100.0 \\
\hline Fluorene & ND & 0.47 & 0.12 & 0.14 & ND & 100.0 & 92.3 & 99.7 & 99.8 & 100.0 \\
\hline Pheenanthrene & 0.69 & 0.25 & 0.30 & 0.78 & 0.19 & 97.2 & 98.2 & 99.2 & 98.6 & 98.6 \\
\hline Fluoranthene & 0.29 & 0.34 & 0.38 & 0.67 & 0.23 & 74.1 & 77.6 & 90.9 & 62.7 & 98.3 \\
\hline Pyrene & 0.72 & 0.43 & 0.38 & 0.37 & 0.31 & 83.3 & 92.5 & 99.0 & 98.0 & 91.2 \\
\hline Benzo(b)fluoranthe & ND & ND & ND & ND & ND & 100.0 & 100.0 & 100.0 & 100.0 & 100.0 \\
\hline Benzo(k)fluoranthene & ND & ND & ND & ND & ND & 100.0 & 100.0 & 100.0 & 100.0 & 100.0 \\
\hline Benzo(a)pyrene & ND & ND & ND & ND & ND & 100.0 & 100.0 & 100.0 & 100.0 & 100.0 \\
\hline
\end{tabular}

\section{RESULTS AND DISCUSSIONS}

\subsection{Characterization of the samples and PAH quantification}

Initially, a pre-quantification of the iron concentration in the samples was carried out to verify the presence of this substance, as well as to use it in the submission of the samples to the photo-Fenton like process. The following amounts for AGM, AJQ, APM, APN, APNL: 12.00, 8.20, 3.94, 2.61 and $25.00 \mathrm{mg} . \mathrm{L}^{-1}$, respectively, were verified. The methodology used in the characterization of effluent for iron (mg/L Fe) was the APHA 3500-Fe $B$, following the Standard Methods for the Examination of Water and Wastewater. The effluent samples of the different points analysed did not present levels of iron above the limit required by the CONAMA 430/2011, of $15.00 \mathrm{mg} \cdot \mathrm{L}^{-}$ ${ }^{1}$, with the exception of the sludge sample; in which the iron level observed was of $25.00 \mathrm{mg} \cdot \mathrm{L}^{-1}$.
Subsequently, all samples were analysed by gas chromatography, combined with mass spectrometry (GC/MS), before the photo-Fenton like process, detecting $10 \mathrm{PAH}$. These were: naphthalene, acenaphthylene, fluorene, phenanthrene, fluoranthene, pyrene, benzo(b)fluoranthene, benzo(k)fluoranthene, and benzo(a)pyrene, see Table 1.

\subsection{PAH degradation via photo-Fenton process}

Once verified the presence of 10 different PAH and quantified the concentration of iron in the samples studied, the degradation of pollutants using the AOP was undertaken. After the treatment, 7 of the PAH were identified: naphthalene, acenaphthylene, acenaphthene, fluorene, phenanthrene, fluoranthene, pyrene. Table 2 presents the results. The other PAHs initially observed (benzo(b)fluoranthene, 


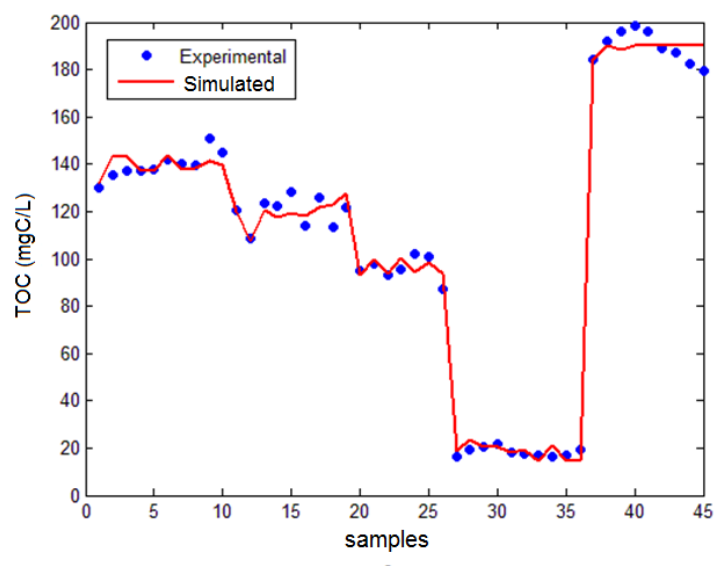

A

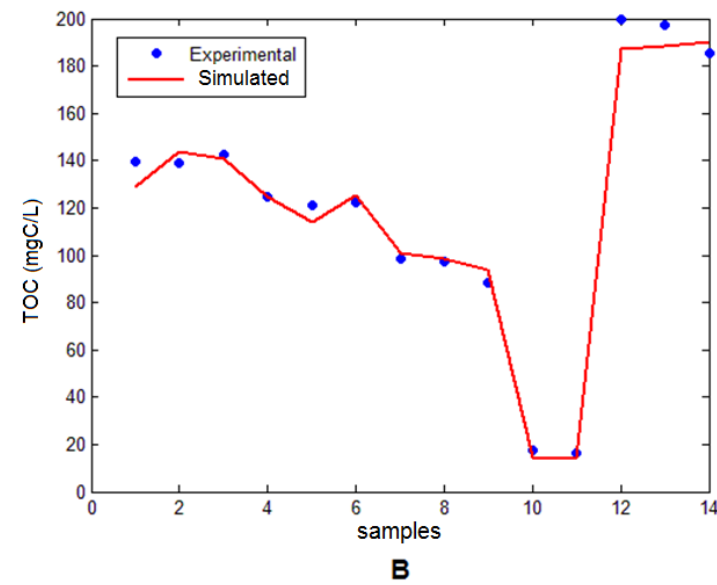

B

Figure 3. Comparison between experimental and simulated data used: A) Trial, B) Test.

benzo(k)fluoranthene, benzo(a)pyrene) were not detected using the GC/MS analysis.

The treatment employed proved efficient in the degradation of the composites analysed, especially for the PAH Benzo(b)fluoranthene, Benzo(k)fluoranthene and Benzo(b)pyrene, which, according to the CONAMA 357/2005 resolution, should present amounts equal or below $0.05 \mu \mathrm{g} \cdot \mathrm{L}^{-1}$. It is important to note that these hydrocarbons were present in the sample before the AOP, with amounts beyond the ones permitted by the legislation. According to Yagishita et al. (2009), promoting the degradation of these pollutants is extremely important, as the three PAH are considered carcinogenic, being the benzo(a)pyrene the most toxic component.

Once run, the analysis on contamination and $\mathrm{PAH}$ removal and the evaluation of the average TOC content was carried out. The samples from the several stages were submitted to the TOC analysis two fold, as presented in Table 2, corroborating with the results from the points collected from the treatment plant. All samples in the conditions studied were degraded, but not completely mineralised. This way, the need of a more energetic treatment becomes evident, either by increasing the amount of peroxide or by using ANN.

\subsection{Modelling using artificial neural networks}

The type of neural network used was the "multilayerperceptron" (MLP), constituted of 3 layers: 1) input layer, containing 10 neurones; 2) hidden layer, containing 3 neurones; and 3) output layer, with 1 neurone. For the first strategy tested, three neurones were used in the intermediary layer, with the logsigactivation function, which was also used in the exit layer. The data was normalised to between 0.1 and 0.9 and divided in $60 \%$ for the training (used in the evaluation of the efficiency of the study), $20 \%$ for the test (not used in the evaluation stage and $20 \%$ for validation (used in the evaluation of the training, with use of automatic stop in case of inefficiency); in this case, the algorithm used was the Levenberg-Marquardt. The comparisons between experimental and simulated data in both trial and test, respectively, are presented in Figure 3.

For the first strategy used in the modelling, without the analysis of the variable time, the trained neural network was acknowledged to have obtained a high degree of correlation for both training $\left(R^{2}=0.997\right)$ and the test $\left(R^{2}=0.995\right)$, as demonstrated in Figure 4.

Once obtained experimental and simulated data used in the training and in the test, the validation was employed, demonstrating the proximity of the values. The neural network was able to follow with precision the data and, consequently, the TOC contents. The correlation coefficient of 0.994 (Figure 5-A) was obtained in accordance to the data from literature (Aleboyeh et al., 2007; Salari et al., 2005; Guimarães et al., 2010; Elmolla et al., 2010; Wenwu et al., 2010; Giroto et al., 2006). 


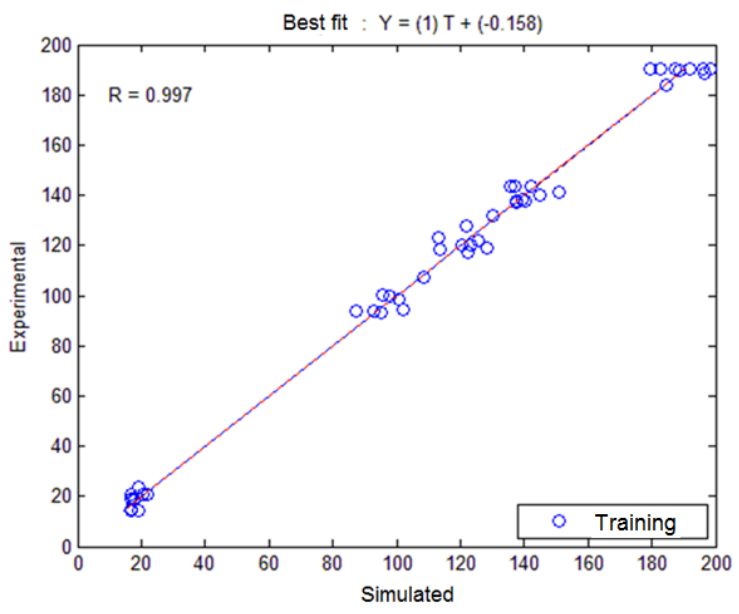

A

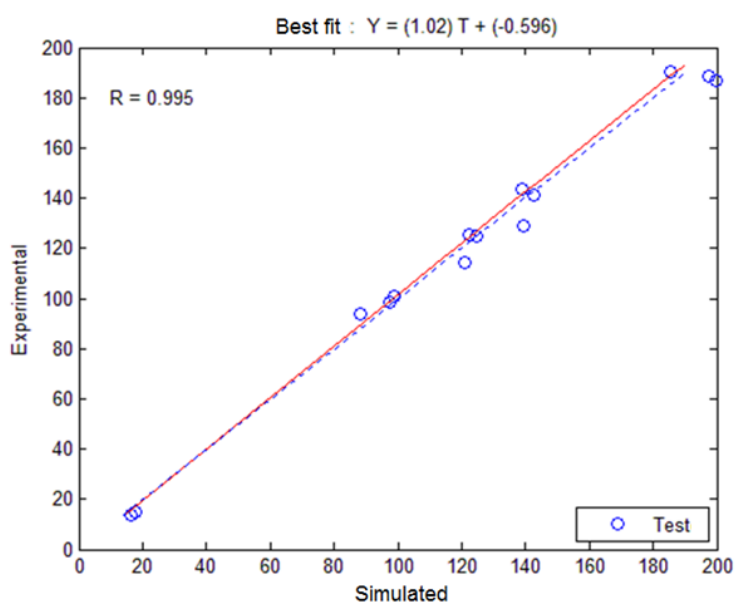

B

Figure 4. Linear Regression Chart between experimental and simulated data used: A) training, B) test.
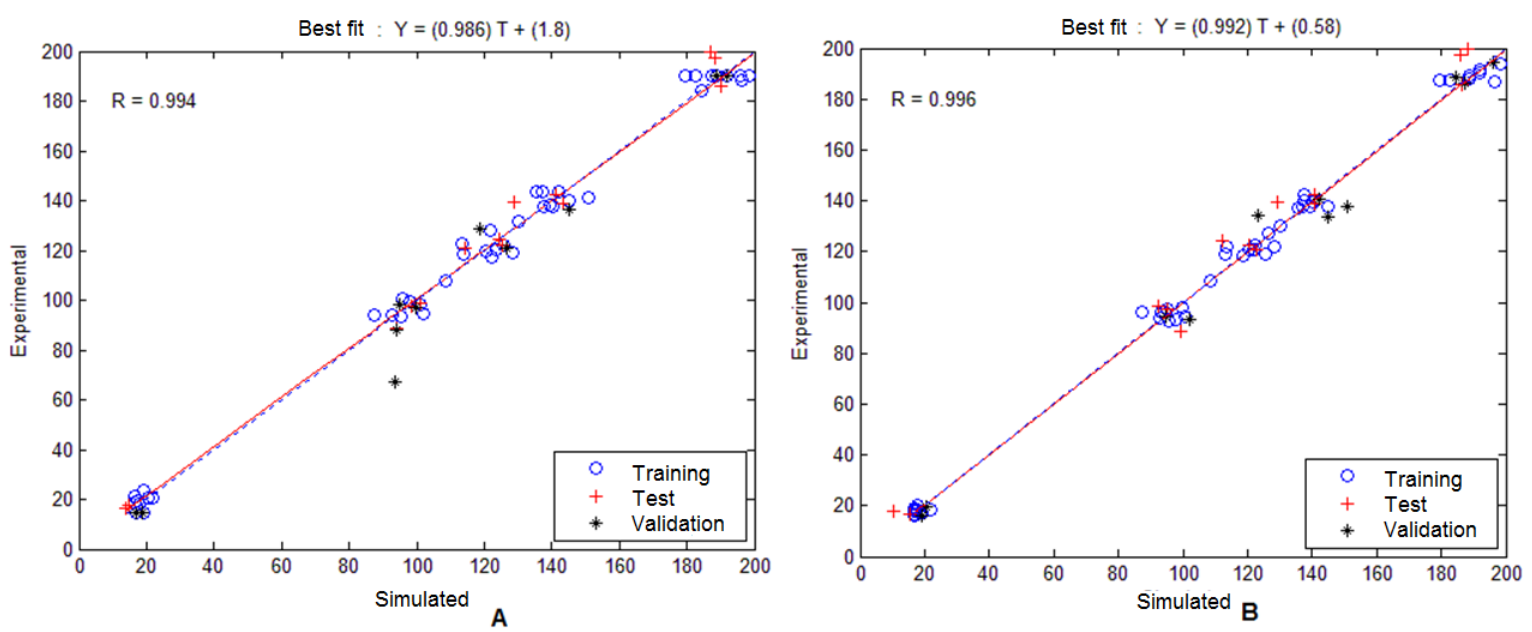

Figure 5. Linear Regression chat between experimental and simulated data in the training, in the test, and in the validation process for: A) the first ANN strategy, B) for the second strategy.

Since the first strategy used in the test and training stages presented a good linear regression, and that only the variable time was added to the second strategy, the same procedure was taken for the second stage. In this case, the way of evaluating the efficiency of the model employed was drawn to a chart for the best adjustment: training, test, and validation process. For the modelling strategy using the variable time, one could note that, among experimental and simulated data used in the data set, the network was able to simulate with reasonable precision the TOC contents (Figure 5-B). Based on this analysis, as well as on the value obtained for the correlation coefficient $\left(R^{2}=0.996\right)$, a good prediction of the experimental results was observed, as described by Dias et al. (2013).

\section{CONCLUSIONS}

The degradation of PAHs to the five samples studied shows that the advanced oxidation processes, complementing the biological processes or by themselves, are effective in the degradation of recalcitrant compounds in the oil industry when treated using the photo-Fenton process, with higher rates of $60 \%$ and $90 \%$ degradation for most experiments, over a relatively short training, up to 30 minutes.

For both neural modeling strategies studied, the treatment time was found to be more efficient when analyzing the correlation coefficient, even with a small amount of data when compared with data in the literature; evidencing the efficiency of 
neural networks in modeling the AOP. Thus, proving that the ANN can describe the efficiency of the complex as a photo-oxidation process, with the comparison of the correlation coefficients between the experimental and simulated data and predicting $O C D$, its output variable.

\section{ACKNOWLEDGEMENTS}

The authors would like to express their upmost gratitude to PRH-28, PETROBRAS, CNPq/APQ, CNPq/INCTAA, FACEPE/NUQAAPE, and CAPES/FCT/MES for the financial support.

\section{REFERENCES}

Aleboyeh, A; Kasiri, M. B.; Olya, M. E.; Aleboyeh, $\mathrm{H}$. Prediction of azo dye decolorization by UV/ $\mathrm{H}_{2} \mathrm{O}_{2}$ using artificial neural networks. Dyes and Pigments, v. 77, p. 288-294, 2007.

http://dx.doi.org/10.1016/j.dyepig.2007.05.014

Alva-Argaéz, A.; Kokossis, A. C.; Smith, R. The design of water-using systems in petroleum refining using a water-pinch decomposition. Chemical engineering Journal, v.128, n.1, p.33-46, 2007. http://dx.doi.org/10.1016/i.cej.2006.10.001

APHA - American Public Health Association. Standard methods for the examination of water and wastewater. $20^{\text {th }}$.ed. New York: APHA, AWWA, WPCR, 2003.

Ana, R. R.; Olga, C. N.; Manuel, F. R. P.; Adrián, M. T. S. An overview on the advanced oxidation processes applied for the treatment of water pollutants defined in the recently launched Directive 2013/39/EU. Environment International, v. 75, p. 33-51, 2005.

Costa, L. R. T. A. Modelo Estratégico de Otimização para a resposta a derramamento de óleo considerando Áreas sensíveis. Tese de Doutorado. Programa de Engenharia de Produção, Universidade Federal do Rio de Janeiro, Rio de Janeiro- Brasil, 2007. (In Portuguese)
Cotta, J. A. O.; Rezende, M. O. O.; Landgraf, M. D. Avaliação de solventes de extração por ultrassom usando-se cromatografia líquida de alta eficiência para a determinação de hidrocarbonetos policíclicos aromáticos em solos contaminados. Instituto de Química de São Carlos, Universidade de São Paulo, São Carlos - SP, Brasil, 2008. (In Portuguese)

Dias, F. F. S.; Chiavone-Filho, O.; Carvalho, F. O.; Pacheco, J. G. Degradação de corante reative black 5 via processo foto-Fenton em reator PTC com modelagem e otimização utilizando RNA. Scientia Plena, v. 9, n. 10, p. 1-12, 2013. (In Portuguese)

Durigan, M. A. B.; Vaz, S. R.; Peralta-Zamora, P. Degradação de poluentes emergentes por processos Fenton e foto-Fenton. Química Nova, v. 35, n. 7, 1381-1387, 2012. (In Portuguese) http://dx.doi.org/10.1590/\$0100-40422012000700018

Ebrahimzadeh, A.; Khazaee, A. Detection of premature ventricular contractions using MLP neural networks: a comparative study. Measurement, v. 43, p. 103-112, 2010. http://dx.doi.org/10.1016/i.measurement.2009.07.002

Elmolla, E. S.; Chaudhuri, M.; Eltoukhy, M. M. The use of artificial neural network (ANN) for modeling of COD removal from antibiotic aqueous solution by the Fenton process. Journal of Hazardous Materials, v. 179, n. 1-3, p. 127-134, 2010. http://dx.doi.org/10.1016/i.jhazmat.2010.02.068

Enell, A.; Reichenberg, F.; Warfvinge, P.; Ewald, G. A column method for determination of leaching of polycyclic aromatic hydrocarbons from aged contaminated soil. Chemosphere, v. 54, p. 707715, 2004.

http://dx.doi.org/10.1016/i.chemosphere.2003.08.026

Falla, F. S.; Larini, C.; Le Roux, G. A. C.; Quina, F. H.; Moro, L. F. L.; Nascimento, C. A. O. Characterization of crude pretoleum by NIR. Journal of Petroleum Science and Engineering, v. 51, n. 1-2, p. 127-137, 2006.

http://dx.doi.org/10.1016/i.petrol.2005.11.014

Giroto, J. A.; Guardani, R.; Teixeira, A. C. S. C.; Nascimento, C. A. O. Study on the photo-Fenton degradation of polyvinyl alcohol in aqueous solution. Chemical Engineering and Processing: Process Intensification, v. 45, n. 7, p. 523-532, 2006. http://dx.doi.org/10.1016/j.cep.2005.12.001 
Guimarães. E. F.; Rego, E. C. P.; Cunha, H. C. M.; Rodrigues. J. M.; Villar, J. D. F.; Cunha, V. S. Validação e Metodologia Analítica para a Determinação de HPA em Solução. Edição Metrologia, Produto e Produção v.11, n.1, p.113123, 2010. (In Portuguese)

Hu, G.; Li, J.; Hou, H. A combination of solvent extraction and freeze thaw for oil recovery from petroleum refinery wastewater treatment pond sludge. Journal of Hazardous Materials, v. 283, p. 832-840, 2015.

http://dx.doi.org/10.1016/j.jhazmat.2014.10.028

Jacques, R. J. S.; Bento, F. M.; Antoniolli, Z. I.; Camargo, F. A. O. Biorremediação de solos contaminados com hidrocarbonetos aromáticos policíclicos. Ciência Rural, v. 37, p. 1192-120, 2007. (In Portuguese) http://dx.doi.org/10.1590/S0103$\underline{84782007000400049}$

Jalil, A.; Ata, E.; Milad, A.; Vahid, R. Statistical process control using optimized neural networks: $A$ case study. ISA Transactions, v. 53, p. 1489-1499, 2014. http://dx.doi.org/10.1016/i.isatra.2013.07.018

Khan, W. S.; Najeeb, I.; Tuiyebayeva, M.; Makhtayeva, Z. Refinery wastewater degradation with titanium dioxide, zinc oxide, and hydrogen peroxide in a photocatalytic reactor. Process Safety and Environmental Protection, v. 94, p. 479 -486, 2015. http://dx.doi.org/10.1016/i.psep.2014.10.007

Khataee, A. R.; Kasiri, M. B. Photocatalytic degradation of organic dyes in the presence of nanostructured titanium dioxide: Influence of the chemical structure of dyes. Journal of Molecular Catalysis A: Chemical, v. 328, n. 1-2, p. 8-26, 2010. http://dx.doi.org/10.1016/j.molcata.2010.05.023

Khowatimya, F. A.; Priastomo, Y.; Febriyanti, E.; Riyantoko, H.; Trisunaryanti, W. Study of Waste Lubricant Hydrocracking into Fuel Fraction over the Combination of Y-Zeolite and ZnO Catalyst. Procedia Environmental Sciences, v. 20, p. 225234, 2014.

http://dx.doi.org/10.1016/i.proenv.2014.03.029

Kim, J. H.; Han, S. J.; Kim, S. S.; Yang, J. W. Effect of soil chemical properties on the remediation of phenanthrene-contaminated soil by electrokinetic Fenton process. Chemosphere, v. 63, p. 1666-1676, 2006.

http://dx.doi.org/10.1016/i.chemosphere.2005.10.008
Kulkarni, S. J.; Tapre, R. W.; Patil, S. V.; Sawarkard, M. B. Adsorption of phenol from wastewater in fluidized bed using coconut shell activated carbon. Procedia Engineering, v. 51, p. 300-307, 2013.

http://dx.doi.org/10.1016/j.proeng.2013.01.040

Liu, Q. Y.; Liu, Y. X.; Lu, X. J. Combined PhotoFenton and Biological Oxidation for the Treatment of Aniline Wastewater. Procedia Environmental Sciences, v. 12, p. 341-348, 2012.

http://dx.doi.org/10.1016/i.proenv.2012.01.287

Misiti, T.; Tesel, U.; Pavlostathis, S. G. Fate and Effect of Naphthenic Acids on Oil Refinery Activated Sludge Wastewater Treatment Systems. Water Research, v. 47, p. 449 - 460, 2013. http://dx.doi.org/10.1016/j.watres.2012.10.036

Mizzouri, N. S.; Shaaban, M. G. Individual and combined effects of organic, toxic and hydraulics shocks on sequencing batch reactor in treating petroleum refinery wastewater. Journal of Hazardous Materials, v. 333, p. 250- 251, 2013. http://dx.doi.org/10.1016/j.jhazmat.2013.01.082

Napoleão, D. C.; Brandão, Y. B.; Benachour, M.; Silva, V. L. Estudo do processo Foto-Fenton para tratamento de fármacos: otimização e modelagem cinética. Scientia Plena, v. 9, n. 9, p. 1-9, 2013. (In Portuguese)

Salari, D.; Daneshvar, N.; Aghazadeh, F.; Khataee, A. R. Application of artificial neural networks for modeling of the treatment of wastewater contaminated with methyl tert-butyl ether (MTBE) by $\mathrm{UV} / \mathrm{H}_{2} \mathrm{O}_{2}$ vprocess. Journal of Hazardous Materials B, v. 125, p. 205-210, 2005. http://dx.doi.org/10.1016/i.jhazmat.2005.05.030

Santaella, S. T.; Silva Júnior, F. C. G.; Gadelha, D. A. C.; Costa, K. O.; Aguiar, R.; Arthaud, I. D. B.; Leitão, R. C. Tratamento de Efluentes de Refinaria de Petróleo em Reatores com Aspergillus Níger. Engenharia Sanitária e Ambiental, v. 14, n. 1, p. 139-148, 2009.

http://dx.doi.org/10.1590/S1413-41522009000100015

Stepnowski, P.; Siedlecka, E. M.; Behrend, P.; Jastorff, B. Enhanced photo-degradation of contaminants in petroleum refinery wastewater. Water Research, v. 36, p. 2167-2172, 2002. http://dx.doi.org/10.1016/S0043-1354(01)00450-X 
Wang, Y.; Zhou, Q.; Peng, S.; Lena, L. Q. M.; Niu, $X$. Toxic effects of crude-oil-contaminated soil in aquatic environment on Carassius auratus and their hepatic antioxidant defense system. Journal of Environmental Sciences, v. 21, p. 612- 617, 2009.

http://dx.doi.org/10.1016/S1001-0742(08)62315-3

Wenwu Y.; Guanrong, C.; Ming C. Some necessary and sufficient conditions for secondorder consensus in multi-agent dynamical systems. Automatica, v. 46(6), 1089-1095, 2010. http://dx.doi.org/10.1016/j.automatica.2010.03.006

Xia, X.; Xia, N.; Lai, Y.; Dong, J.; Zhao, P.; Zhu, B.; Liz, Z.; Ye, W.; Yuan, Y.; Huang, J. Response of PAHdegrading genes to $\mathrm{PAH}$ bioavailability in the overlying water, suspended sediment, and deposited sediment of the Yangtze River. Chemosphere, v. 128, p. 236-244, 2015.

http://dx.doi.org/10.1016/i.chemosphere.2015.02.011
Xu, P.; Han, H.; Hou, B.; Zhuang, H.; Jia, S.; Wang, D.; Li, K.; Zhao, Q. The feasibility of using combined $\mathrm{TiO}_{2}$ photocatalysis oxidation and MBBR process for advanced treatment of biologically pretreated coal gasification wastewater. Bioresource Technology, v. 189, p.417-420, 2015. http://dx.doi.org/10.1016/i.biortech.2015.04.051

Yagishita, M.; Kageyama, S.; Ohshima, S.; Matsumoto, M.; Aoki, Y.; Goto, S.; Nakajima, D. Atmospheric concentration and carcinogenic risk of polycyclic aromatic hydrocarbons including benzo[c]fluorene, cyclopenta[c,d] pyrene, and benzo[j]fluoranthene in Japan. Atmospheric Environement, v. 115, p. 263-268, 2015. http://dx.doi.org/10.1016/i.atmosenv.2015.05.050 